Journal of Finance Research

\title{
Study on the Relationship Between the Audit Committee of Ipo Firms and the First-Day Stock Earnings
}

\section{Zhangying She ${ }^{*}$}

Monash University, Melbourne, Victoria, 00008C, Australia

\begin{tabular}{|c|c|}
\hline ARTICLE INFO & ABSTRACT \\
\hline Article history & \multirow{6}{*}{$\begin{array}{l}\text { This paper mainly discusses the relationship between the audit committee } \\
\text { of IPO firms and the stock returns on the first day of trading on the stock } \\
\text { exchange. Using the sample of } 21 \text { firms that made an initial public offer- } \\
\text { ing in ASX between } 2008 \text { and } 2010 \text {, Regression analysis was used to con- } \\
\text { clude that the existence of the audit committee of IPO firms and listed on } \\
\text { the first day of the stock returns have no significant direct relationships. } \\
\text { The result shows that the audit committee has no effect on the earnings of } \\
\text { the first day of listing, and the establishment of the audit committee may } \\
\text { not be considered before listing. }\end{array}$} \\
\hline Received: 12 May 2020 & \\
\hline Revised: 19 May 2020 & \\
\hline Accepted: 9 October 2020 & \\
\hline Published Online: 16 October 2020 & \\
\hline $\begin{array}{l}\text { Keywords: } \\
\text { IPO firms }\end{array}$ & \\
\hline
\end{tabular}

Listed firms

Audit committee

Regression analysis

\section{Introduction}

$\mathrm{W}$ ith the emergence of profile financial and accounting scandals in the early 21 st century, the Sarbanes-Oxley Act emphasized the importance and functions of the audit committee. Since then, the public emphasize the existence of the audit committee and scholars are interested in the impact of the audit committee on the company in different aspects (Defond and Francis, 2005). This article aims to examine whether the IPO firms' audit committee will affect the stock returns on the first day of trading on the stock exchange. The audit committee could enhance corporate governance, strengthen oversight, and ensure the quality of financial reporting, which influences stock price and returns indirectly. ${ }^{[1]}$ Although similar studies have been conducted in previous literature, the amount of literature is not sufficient, and they choose non-Australian IPO companies as objects. Prior research is rarely involved in companies listed in the ASX. Therefore, this article uses the empirical analysis method, selects 21 ASX listed companies which become IPO during 2008-2010, and conduct the regression analysis to study the relationship between IPO firms' audit committee and stock returns on the first day of trading on the stock exchange. The result contributes to enrich the literature on audit committees and stock returns in Australia, as well as explore the influence of audit committees on stock return to provide a reference for pre-IPO companies to determine to establish audit committees or not.

\section{Literature Review}

There's a lot of research on audit committees and stock

\footnotetext{
*Corresponding Author:

Zhangying She,

Female,

Master degree in Monash University;

Research direction: accounting and finance;

E-mail:314516081@qq.com.
} 
returns. Azzoz and Khamees (2016) suggest the audit committee can be used as a factor to measure the corporate governance mechanisms. The existence of the audit committee improves the controlling and monitoring process of the company. ${ }^{[2]}$ They select financial companies listed in the Amman Stock Exchange (ASE) for the period span 2007 to 2012 and conclude that there is a statistical relationship between stock return and the audit committee. Vander Zahn (2008) examines the relationship between different personal characteristics of the audit committee members of IPO companies and the level of first-day return. The sample of 322 Singapore IPOs listing on the Stock Exchange of Singapore (SGX) from 1997 to 2004 is utilized in regression analysis, and empirical results indicate no overwhelming association between the personality features of IPO audit committees and first-day returns. Beasley (1996) states that a functioning and independent audit committee can enhance the quality of disclosure, ensure the authenticity and reliability of financial information, and effectively reduce the probability of fraud. Haggard, Martin, \& Pereira (2008) point that more disclosure and better transparency can enhance investors' trust and confidence in the company and more disclosure of information can enable investors to make more accurate assessments and make investment decisions, which contributes to the increase of stock prices. ${ }^{[3]}$ Combined with the aforementioned literature, the existence of an audit committee has a positive effect on the quality of corporate governance and information disclosure, which influences the stock return indirectly. However, previous researches focus on various objective. There is no clear literature states that the correlation between the existence of the IPO firm's audit committee and the first-day stock returns is positive or negative.

\section{Hypothesis Development}

The audit committee contributes to a relatively higher level and more efficient corporate governance, improves companies control activities, and enhances the cooperation between internal and external auditors. The functioning audit committee could improve the quality of financial reports, enhance the transparency of the company, reduce the information asymmetry, and transfer more useful and credible information for investors and the public. The information users will evaluate the company and predict the future operation condition more accurately, which increases investors' confidence in the company. ${ }^{[4]}$ Based on the efficient market hypothesis, the impacts caused by the auditor committee will increase the stock price and investors will demand a lower return, the stock return will decrease. According to the above analysis, the following hypothesis is put forward.

Hypothesis 1: The presence of IPO firms' audit committee is negatively associated with the stock returns on the first day of trading on the stock exchange.

\section{Research Method}

This paper uses the empirical analysis method. Microsoft Excel is used to conduct the regression analysis. The detailed definition of variables and raw data are displayed in Tables 1 and Table 2 respectively. LNRETRUN is the dependent variable. AUDCOM the variable of interest. The BIGN, LNBSIZE and LNASSETS are the control variables. The $\varepsilon$ is the error term. The regression models are designed as follows.

\section{LNRETURNi $=\beta_{0}+\beta_{1}$ AUDCOMi $+\beta_{2}$ BIGNi $+\beta_{3}$ LNBSIZEi $+\beta_{4}$ LNASSETSi $+\varepsilon i$}

As for the data and sample selection, this paper randomly selected 21 companies that made an initial public offering in ASX during 2008-2010, and ignore FUND and TRUST. The closing price of IPO's first day is collected from Yahoo Finance. The rest of the data comes from the IPO prospectus or disclosure documents released in the DatAnalysis premium ${ }^{[5]}$ The raw data is exhibited in Appendix A.

Table 1. Definition of variables used in regression analysis

\begin{tabular}{|c|c|}
\hline $\begin{array}{c}\text { Abbrevia- } \\
\text { tion }\end{array}$ & Definition \\
\hline $\begin{array}{c}\text { LNRE- } \\
\text { TURN }\end{array}$ & $\begin{array}{r}\text { Natural logarithm of (1 + stock returns of an IPO firm on the } \\
\text { first day of trading on ASX) }\end{array}$ \\
\hline $\begin{array}{c}\text { AUD- } \\
\text { COM }\end{array}$ & $\begin{array}{r}\text { Dummy variable set to one if an IPO firm has the presence } \\
\text { of an audit committee and zero otherwise }\end{array}$ \\
\hline BIGN & $\begin{array}{c}\text { Dummy variable set to one if an IPO firm employs an exter- } \\
\text { nal auditor from the member of BIGN and zero otherwise. } \\
\text { The BIGN includes Ernst \& Young, PricewaterhouseCoo- } \\
\text { pers, KPMG and Deloitte Touche Tohmatsu. }\end{array}$ \\
\hline LNBSIZE & $\begin{array}{c}\text { Natural logarithm of the number of directors on the board of } \\
\text { an IPO firm }\end{array}$ \\
\hline $\begin{array}{c}\text { LNAS- } \\
\text { SETS }\end{array}$ & $\begin{array}{c}\text { Natural logarithm of total assets value recognized on the } \\
\text { proforma balance sheet of an IPO firm }\end{array}$ \\
\hline I & An IPO firm \\
\hline
\end{tabular}

Table 2. Raw data collected from IPO prospectuses

\begin{tabular}{|c|c|}
\hline $\begin{array}{c}\text { Abbrevia- } \\
\text { tion }\end{array}$ & Definition \\
\hline RETURN & $\begin{array}{c}\text { Stock return on the first day of trading on the stock ex- } \\
\text { change of an IPO firm (infraction) }=\text { (Closing share price } \\
\text { on the first day of trading on the stock exchange - IPO issue } \\
\text { price)/IPO issue price) }\end{array}$ \\
\hline BSIZE & $\begin{array}{c}\text { Number of directors on the board of an IPO firm disclosed } \\
\text { in the IPO prospectus }\end{array}$ \\
\hline ASSETS & $\begin{array}{c}\text { Number of directors on the board of an IPO firm disclosed } \\
\text { in the IPO prospectus }\end{array}$ \\
\hline
\end{tabular}




\section{Results}

The descriptive statistics and regressions results are displayed as Table 3 and Table4.

Table 3. Descriptive statistics

\begin{tabular}{|c|c|c|c|c|c|c|}
\hline & Mean & Median & $\begin{array}{c}\text { Standard } \\
\text { Deviation }\end{array}$ & Min & Max & N \\
\hline LNRETURN & 0.30741075 & 0.09531018 & 0.64856615 & -0.21072103 & 2.19555652 & 21 \\
\hline AUDCOM & 0.57142857 & 1 & 0.50709255 & 0 & 1 & 21 \\
\hline BIGN & 0.38095238 & 0 & 0.49761335 & 0 & 1 & 21 \\
\hline LNBSIZE & 1.44815950 & 1.38629436 & 0.24899847 & 1.09861229 & 1.79175947 & 21 \\
\hline LNASSETS & 16.63268172 & 16.23046584 & 1.44772821 & 13.94443134 & 20.43295765 & 21 \\
\hline RETURN & 0.86700711 & 0.1 & 2.309827935 & -0.19 & 7.985 & 21 \\
\hline BSIZE & 4.38095238 & 4 & 1.07126983 & 3 & 6 & 21 \\
\hline ASSETS & 61155744.81 & 11189270 & 160865476.42 & 1137600 & 748033000 & 21 \\
\hline
\end{tabular}

Table 3 exhibits Mean, Median, Standard Deviation Min Max, and N of each variable. The Mean of LNRETURN is 0.30741075 , the Minimum and Maximum -0.21072103 and 2.19555652 respectively. The mean of AUDCOM is $58 \%$, which suggests more than half IPO companies own the audit committee. $38 \%$ of 21 companies use BIG4 audit firms as their auditor. The range of Return is from -0.19 to 7.985. As for the board size, the average director number is 4 (rounded), the company with the least board of directors has 3 board members and the largest is 5 . There is also a wide gap in total assets between companies, ranging from 1137600 to 748033000 , the mean is 61155744.81 .

Table 4. Regression results

\begin{tabular}{|c|c|c|c|c|}
\hline & Coefficients & $\begin{array}{c}\text { Standard } \\
\text { Error }\end{array}$ & t Stat & P-value \\
\hline Intercept & -0.955510312 & 2.265974086 & -0.421677511 & 0.678871 \\
\hline LNASSETS & 0.074077267 & 0.143488659 & 0.51625869 & 0.612735 \\
\hline LNBSIZE & 0.224442655 & 0.688379095 & 0.326045136 & 0.748616 \\
\hline AUDCOM & -0.586442749 & 0.363076853 & -1.615202799 & 0.125811 \\
\hline BIGN & 0.107359449 & 0.435708662 & 0.246401916 & 0.808504 \\
\hline Number of observations & 21 & & \\
\hline \multicolumn{2}{|c|}{ R Square } & 0.157255488 & & \\
\hline \multicolumn{2}{|c|}{ Adjusted R Square } & -0.05343064 & & \\
\hline \multicolumn{2}{|c|}{ Standard Error } & 0.665667341 & & \\
\hline
\end{tabular}

Table 4 exhibits the regression result. The $\mathrm{R}$ square is about $20 \%$, which indicates $20 \%$ of the sample could be explained by the regression model. The coefficient of AUDCOM is -0.586442749 , which reveals there is a negative relationship between LNRETURN and AUDCOM. The corresponding P-value is 0.125811 , which is larger than 0.1 , it states the coefficient is statistically insignificant. In conclusion, the LNRETURN is statistically insig- nificant and negative with the AUDCOM, which cannot support the Hypothesis 1.

\section{Conclusion}

This article aims to examine whether the IPO firms' audit committee will affect the stock returns on the first day of trading on the stock exchange. Due to the statistically insignificant and negative relationship between the LNRETURN and AUDCOM, the hypothesis is not supported. We can't prove that there is a clear connection between the IPO firms' audit committee and stock returns on the first day of trading on the ASX.

\section{Limitation of Study and Future Research}

This article owns the following limitations.

a) The sample is too small, the regression results are easily influenced by extreme value, which leads to the inaccuracy of the regression result. Otherwise, the R square is only $20 \%$, which means the regression model only explains about $20 \%$ of the sample, is not persuasive and lack of representativeness.

b) Only companies listed in ASX between 2008 and 2010 have been sampled. The time range is relatively short. The impact of the audit committee on the company will change over time, so the time range should be expanded and also collected samples from other stock exchange because Different stock exchanges have different conditions for listing

c) This paper only considers the existence of the audit committee, but does not set up indicators to measure the effectiveness of the audit committee. Only when the audit committee is running functioning, it can accord with our hypothetical development. This metric should be set in the future research.

\section{References}

[1] Azzoz, A.-R. A., \& Khamees, B. A. (2016). The Impact of Board of Directors and Audit Committees on Stock Return of Jordanian Financial Companies. Dirasat: Administrative Sciences, 43(2), 923-942. Retrieved from http://ezproxy.lib.monash. edu.au/login?url=http://search.ebscohost.com/login. aspx?direct $=$ true $\& \mathrm{db}=\mathrm{bth} \& \mathrm{AN}=123863686 \&$ site $=\mathrm{e}-$ host-live \&scope $=$ site

[2] Beasley, M. S. (1996). An Empirical Analysis of the Relation Between the Board of Director Composition and Financial Statement Fraud. Accounting Review, 71(4), 443-465. Retrieved from http:// ezproxy.lib.monash.edu.au/login?url=http://search. ebscohost.com/login.aspx?direct $=$ true $\& d b=b$ - 
th\&AN $=9611271988 \&$ site $=$ ehost-live $\&$ scope $=$ site

[3] DeFond, M. L., \& Francis, J. R. (2005). Audit Research after Sarbanes-Oxley. Auditing: A Journal of Practice \& Theory, 24(s-1), 5-30

[4] Haggard, K. S., Martin, X., \& Pereira, R. (2008). Does Voluntary Disclosure Improve Stock Price Informativeness?. Financial Management, 37(4), 747768 .
[5] Van der Zahn, J.-L. W. M. (2008). Educational Qualifications, Business Experience and Diversity Factors of Independent Audit Committee Members and an IPO's First-Day Returns. ICFAI Journal of Audit Practice,5(2), 7-41. Retrieved from http:// ezproxy.lib.monash.edu.au/login?url=http://search. ebscohost.com/login.asp $\mathrm{x}$ ?direct $=$ true $\& \mathrm{db}=\mathrm{b}$ th\&AN $=31614287 \&$ site $=$ ehost-live $\&$ scope $=$ site

\section{Appendices}

\begin{tabular}{|c|c|c|c|c|c|c|c|c|c|}
\hline $\mathrm{No}$ & A SX CODE & LN RETU RN & LN A SSETS & LN BSZE & AUDCOM & $\mathrm{B} \mathbf{G N}$ & $\begin{array}{c}\text { RETURN } \\
(\mathbb{N} \text { FRACT10N ) }\end{array}$ & $\begin{array}{c}\text { BSZ E } \mathbb{E} \text { UM BER } \\
\text { OF D RECTORS } \\
\text { ON THE BOARD ) }\end{array}$ & $\begin{array}{l}\text { ASSETS } \\
(\mathrm{AU} \$)\end{array}$ \\
\hline 1 & A TC & -0.020202707 & 15.56563225 & 1.386294 & 0 & 0 & -0.02 & 4 & $5,755,303$ \\
\hline 2 & $1 \mathrm{AG}$ & 0.083881484 & 15.9044454 & 1.791759 & 0 & 0 & 0.0875 & 6 & $8,076,308$ \\
\hline 3 & A A J & -0.210721031 & 15.39051022 & 1.098612 & 0 & 0 & -0.19 & 3 & $4,830,740$ \\
\hline 4 & $A \mathbb{R}$ & 0.433080275 & 13.94443134 & 1.609438 & 1 & 0 & 0.542 & 5 & $1,137,600$ \\
\hline 5 & $\mathrm{AUC}$ & -0.139262067 & 15.83491317 & 1.386294 & 1 & 0 & -0.13 & 4 & $7,533,823$ \\
\hline 6 & $\mathrm{ABX}$ & 0.438254931 & 15.60443117 & 1.609438 & 0 & 0 & 0.55 & 5 & $5,982,991$ \\
\hline 7 & $\mathrm{CM} \mathrm{M}$ & 0.300104592 & 16.34960515 & 1.386294 & 1 & 0 & 0.35 & 4 & $12,605,013$ \\
\hline 8 & EFE & 0.371563556 & 15.46591247 & 1.386294 & 1 & 0 & 0.45 & 4 & $5,209,073$ \\
\hline 9 & EVS & -0.008032172 & 16.59246474 & 1.386294 & 1 & 1 & -0.008 & 4 & $16,070,000$ \\
\hline 10 & $\mathrm{EPW}$ & 0.033711057 & 20.43295765 & 1.791759 & 1 & 1 & 0.034285714 & 6 & $748,033,000$ \\
\hline 11 & FDM & 0.09531018 & 17.37653746 & 1.386294 & 1 & 1 & 0.1 & 4 & $35,199,325$ \\
\hline 12 & $\mathrm{GCY}$ & -0.077961541 & 16.23046584 & 1.098612 & 0 & 0 & -0.075 & 3 & $11,189,270$ \\
\hline 13 & $\mathrm{HCH}$ & 0.048790164 & 15.91061283 & 1.098612 & 0 & 0 & 0.05 & 3 & $8,126,272$ \\
\hline 14 & $\mathbb{R D}$ & 0.270027137 & 15.44448793 & 1.098612 & 0 & 0 & 0.31 & 3 & $5,098,658$ \\
\hline 15 & M LD & 0.371563556 & 18.68545443 & 1.609438 & 1 & 0 & 0.45 & 5 & $130,313,603$ \\
\hline 16 & M YE & 0.09531018 & 17.83495196 & 1.609438 & 1 & 1 & 0.1 & 5 & $55,670,000$ \\
\hline 17 & PD I & 2.148850993 & 16.12768156 & 1.609438 & 0 & 0 & 7.575 & 5 & $10,096,320$ \\
\hline 18 & RFX & -0.15082289 & 16.98654846 & 1.386294 & 1 & 1 & -0.14 & 4 & $23,832,207$ \\
\hline 19 & RVA & 0.127833372 & 18.11370711 & 1.791759 & 1 & 1 & 0.136363636 & 6 & $73,567,000$ \\
\hline 20 & TER & 2.19555652 & 18.26669644 & 1.098612 & 0 & 1 & 7.985 & 3 & $85,728,548$ \\
\hline 21 & XAM & 0.048790164 & 17.22386848 & 1.791759 & 1 & 1 & 0.05 & 6 & $30,215,587$ \\
\hline
\end{tabular}

Appendix A Raw Data-Set 